\title{
PELATIHAN PEMBELAJARAN NILAI-NILAI MORAL ANAK USIA DINI DENGAN PENDEKATAN PSIKOLOGIS DI IGABA (IKATAN GURU BUSTANUL ATHFAL) BANYUMAS
}

\author{
Zakiyah $^{1}$ dan Ibnu Hasan ${ }^{2}$ \\ ${ }^{1}$ Universitas Muhammadiyah Malang \\ ${ }^{2}$ Universitas Muhammadiyah Malang
}

\begin{abstract}
ABSTRAK
Pengabdian berjudul : "Pelatihan Pembelajaran Nilai-nilai Moral Anak Usia Dini dengan Pendekatan Psikologis di IGABA (Ikatan Guru Bustanul Athfal Aisyah) Banyumas" bertujuan untuk memberikan tiga bekal pada mitra, yaitu : 1. Pemahaman dan wawasannya dengan pembelajaran nilai-nilai moral anak usia dini berdasarkan pendekatan psikologis; 2. Memberikan kemampuan dan keterampilan yang memadai tentang pembelajaran nilai-nilai moral anak usia dini dengan pendekatan psikologis sehingga pembelajaran akan semakin berhasil; 3. Kemampuan praktek langsung pembelajaran nilai-nilai moral anak usia dini dengan pendekatan psikologis. Mitra yang dilibatkan adalah 40 guru yang terdaftar di IGABA (Ikatan Guru Bustanul Athfal Aisyiyah). Metode pelaksanaan dengan menggunakan metode komprehensif, dalam arti melibatkan mitra sejak awal pelaksanaan sampai akhir pengabdian yakni dengan cara mengajak mitra mengidendifikasi persoalan-persoalan yang menyangkut kesulitan mitra dalam hal pembelajaran nilai-nilai moral anak usia dini. Disamping itu melibatkan mitra untuk ikut terlibat langsung dalam kegiatan dengan cara memberikan kesempatan yang seluas-luasnya kepada mitra untuk bertanya, menanggapi dan berbagi pengalaman. Langkah kegiatan meliputi : 1 . orientasi materi dengan cara pemaparan materi oleh narasumber; 2. memberikan contoh kongkrit pendekatan psikologis dalam pembelajaran nilai-nilai moral anak usia dini; 3. memberikan praktek langsung pendekatan psikologis dalam pembelajaran nilai-nilai moral usia dini
\end{abstract}

Hasil kegiatan menujukkan tiga hal, yaitu : 1. Bertambahnya pemahaman dan wawasan yang komprehensif mitra tentang pembelajaran nilai-nilai moral anak usia dini dengan pendekatan psikologis, dibuktikan dari hasil wawancara $95 \%$ mitra mengatakan pemahaman dan wawasannya bertambah; 2. Tingkat kemampuan dan ketrampilan mitra tentang pembelajaran nilai-nilai moral anak usia dini dengan pendekatan psikologis juga meningkat terbukti dari hasil wawancara $85 \%$ mitra meningkat kemampuan dan ketrampilannya; 3. Kemampuan mitra saat praktek langsung pembelajaran nilai-nilai moral anak usia dini dengan pendekatan psikologis juga memadai terbukti dari hasil observasi 85\% mitra mampu melaksanakan praktek

Kata-kata kuci : Pembelajaran, Nilai Moral, Psikologis 


\title{
Islãmadîna \\ JURNAL PEMIKIRAN ISLAM
}

Volume XVIII, No. 2, Juni 2017 : 107-120

\author{
ABSTRACT \\ LEARNING TRAINING MORAL VALUES OF EARLY AGE WITH \\ PSYCHOLOGICAL APPROACH IN IGABA \\ (TEACHER BUSTANUL ATHFAL) BANYUMAS
}

Devotion entitled: "Training of Learning Moral Values of Early Childhood with Psychological Approach at IGABA (Teachers Association Bustanul Athfal Aisyah) Banyumas" aims to provide three provisions to partners, namely: 1 . Understanding and his insight by learning the moral values of children aged early on psychological approach; 2. Provide adequate skills and skills about learning the moral values of early childhood with psychological approach so that learning will be more successful; 3. The ability of direct practice of learning early childhood moral values with psychological approach.

Partners involved were 40 teachers enrolled at IGABA (Teachers Association of Bustanul Athfal Aisyiyah). The method of implementation by using a comprehensive method, in the sense of involving partners from the beginning of the implementation to the end of devotion is to invite partners to identify issues related to the difficulties of partners in terms of learning the moral values of early childhood. Besides, it involves partners to be directly involved in the activities by providing the partners with the widest opportunity to ask, respond and share experiences. Steps of activities include: 1. material orientation by way of material exposure by resource persons; 2 . provide concrete examples of psychological approaches in learning the moral values of early childhood; 3. provide a direct practice of psychological approach in the learning of moral values of early age

The results of the activities show three things, namely: 1. Increased understanding and comprehensive insight of partners about learning early childhood moral values with psychological approaches, evidenced from the interviews $95 \%$ of partners said the understanding and insight increased; 2 . The level of ability and skills of partners about learning the moral values of early childhood with psychological approaches also increased as evidenced by interviews $85 \%$ partners increased ability and skill; 3 . The ability of partners when the practice of direct learning of moral values of early childhood with psychological approach is also sufficient evident from the observation $85 \%$ of partners are able to carry out the practice

Keywords: Learning, Moral Values, Psychological 


\section{PENDAHULUAN}

Pembelajaran nilai-nilai moral anak usia dini merupakan salah satu pembelajaran yang diberikan kepada anak usia dini, bahkan pembelajaran nilai-nilai moral merupakan ruhnya pendidikan. Dalam arti inti dari pendidikan sebenarnya adalah teraplikasikannya nilai-nilai moral dalam kehidupan anak. Oleh karena itu merupakan keniscayaan pendidikan tanpa membentuk moral anak. Sebagaimana disebutkan dalam Permendiknas Nomor 58 Tahun 2009 tentang Standar Pendidikan Anak Usia Dini (PAUD) bahwa pendidikan anak usia dini harus memuat nilai-nilai agama dan moral, disamping aspek kognitif, bahasa, sosial emosional dan lain-lain.

Sementara itu Keputusan Menteri Agama Republik Indonesia Nomor 211 Tahun 2011 tentang Pedoman Pengembangan Standar Nasional Pendidikan Agama Islam pada sekolah pada poin Standar Pendidikan Agama Islam pada PAUD disebutkan bahwa : "Standar isi Pendidikan Agama Islam pada PAUD/ TK terdiri atas standar pengalaman yang meliputi : pertama, pengamalan dalam hubungan dengan Allah SWT. Kedua, pengamalan dalam hubungan dengan diri sendiri. Ketiga, pengamalan dalam hubungan dengan sesama manusia. Keempat, pengamalan dalam hubungan dengan lingkungan".

Hidayat (2007 : 7) menyatakan bahwa pendidikan nilai-nilai moral pada program PAUD merupakan pondasi yang kokoh dan sangat penting keberadaannya, dan jika hal itu telah tertanam serta terpatri dengan baik dalam setiap insan sejak dini, hal tersebut merupakan awal yang baik bagi pendidikan anak bangsa untuk menjalani pendidikan selanjutnya. Namun dalam realitasnya dewasa ini terdapat sesuatu yang memprihatinkan dalam dunia pendidikan. Salah satu di antaranya adalah masih banyak output pendidikan yang belum mencerminkan kepribadian yang bermoral, seperti sering tawuran antar pelajar, penyalahgunaan obat-obat terlarang, pelecehan seksual, pergaulan bebas, dan masih banyak perilaku buruk lain.

Jika ditelusuri lebih dalam sebenarnya keadaan yang demikian itu tidak lepas dari dasar pendidikannya pada masa sebelumnya yakni ketika anak dalam usia PAUD, yang boleh jadi pada masa itu pengokohan mental-spritualnya dan moral anak masih belum tersentuh secara maksimal, sehingga akhir-akhir ini anak-anak cenderung menunjukkan perilaku yang menyimpang dan melanggar norma, baik norma agama, hukum, norma sosial, maupun norma moral. Perilaku tersebut merupakan efek panjang dari kegagalan pendidikan moral baik dari orang tua, guru, maupun tokoh masyarakat.

Beberapa faktor yang disinyalir menjadi penyebab kegagalan pendidikan 


\section{Islãmadîna \\ JURNAL PEMIKIRAN ISLAM}

nilai-nilai moral di tingkat PAUD diantaranya adalah pendekatan pembelajaran yang digunakan kurang sesuai dengan psikologis anak. Disinilah perlunya pembelajaran nilai-nilai moral anak usia dini dengan pendekatan psikologis agar pembelajaran nilai-nilai moral anak berhasil secara efektif dan efesien.

IGABA (Ikatan Guru Bustanul Athfal Aisyiyah) Banyumas adalah perkumpulan para guru TK Aisyiyah se-Kabupaten Banyumas yang beranggotakan guru-guru yang mengajar di TK Aisyiyah se-Kabupaten Banyumas. Sedangkan yang mengikuti kegiatan IGABA merupakan guru yang mewakili sekolah TK yang berjumlah 40 orang. Perkumpulan ini mempunyai misi untuk meningkatkan pembelajaran di TK Aisyiyah se Kabupaten Banyumas. Perkumpulan IGABA ini ada dalam tanggung jawab Majelis Pendidikan Dasar dan Menengah (Dikdasmen) Pimpinan Daerah Aisyiyah (PDA) Banyumas.

Beberapa program yang sudah dilaksanakan diantaranya adalah penyelenggaraan seminar pendidikan ke-TK-an, workshop Kurikulum 2013, dan kegiatan lain yang menunjang pembelajaran di TK. Kegiatan-kegiatan yang dilakukan pada dasarnya untuk membekali dan menambah wawasan dan keterampilan para guru TK yang mengajar di TK Aisyiyah se-Kabupaten Banyumas sehingga para guru TK Aisyiyah semakin profesional dalam menjalankan tugasnya dan tidak ketinggalan perkembangan ilmu dan teknologi sehingga berpengaruh terhadap penyiapan peserta didik yang mumpuni dan siap melanjutkan pada jenjang pendidikan selanjutnya.

Kondisi mitra (para guru yang tergabung dalam IGABA Banyumas) saat ini merupakan kelompok yang perlu mendapat perhatian khusus dengan memberikan pelatihan pembelajaran nilai-nilai moral dengan pendekatan psikologis untuk membekali mitra menjadi guru yang profesional, kreatif, inovatif, dan mumpuni dalam menjalankan tugasnya, sehingga kegiatan pelatihan menjadi hal yang sangat penting dan mendesak untuk dilaksanakan karena para guru inilah yang membekali anak dengan nilai-nilai moral yang nantinya akan menjadi landasan berperilaku anak dan akan dipraktekan anak dalam menghadapi masa-masa selanjutnya, disamping juga untuk menyongsong masa depan yang lebih baik dengan menyiapkan peserta didik yang berakhlaq mulia dan berkarakter.

\section{MATERI DAN METODE}

Materi pelatihan sebagai berikut : pertama, pembelajaran nilai-nilai moral anak usia dini dengan pendekatan spiritual yang meliputi : (a)kajian tentang nilai-nilai moral; (b)pola perkembangan nilai-nilai moral anak usia dini; (c)pentingnya pembelajaran nilai-nilai moral anak usia dini; (d)pengaruh 
pendekatan pembelajaran terhadap keberhasilan pembelajaran; (e)pendekatan psikologis; (f)karakteristik psikiologis anak usia dini. Kedua, praktek langsung pembelajaran nilai-nilai moral anak usia dini dengan pendekatan psikologis oleh peserta yang dibimbing oleh narasumber dan peserta lain memberikan masukan dan tanggapan untuk kesempurnaan pemahaman peserta.

Kegiatan pelatihan menggunakan metode yang variatif, diawali dengan pemaparan materi untuk menjelaskan tentang berbagai hal yang terkait dengan pembelajaran nilai-nilai moral anak usia dini dengan pendekatan psikologis sehingga pembelajaran akan berhasil secara efektif dan efesien. Metode yang digunakan dengan tanya jawab dan berbagi dengan peserta akan berbagai hal yang terkait dengan pembelajaran nilai-nilai moral anak usia dini dengan pendekatan psikologis.

Metode tanya jawab yang demikian ternyata mampu menghidupkan suasana yakni para peserta antusias untuk memberikan tanggapan dan berbagi dengan narasumber. Disamping juga digunakan metode praktek langsung dengan cara meminta beberapa peserta untuk praktek di depan peserta lain dan diobservasi narasumber untuk mengatahui kemampuan dan keterampilan peserta pelatihan.

\section{HASIL DAN PEMBAHASAN}

\section{Hasil Kegiatan}

1. Pemahaman dan Pengetahuan Peserta Sebelum Pelatihan

Pelatihan ini menekankan pada aspek model pembelajaran, aspek nilai-nilai moral, aspek anak usia dini, dan aspek psikologis. Pada umumnya peserta memiliki kemampuan yang cukup dalam inovasi dan kreativitas model pembelajaran karena latar belakang pendidikan yang cukup dan pencarian pengetahuan secara otodidak maupun belajar dari yang sudah berpengalaman.

Pembelajaran dipahami peserta sebagai interaksi peserta didik dengan pendidik dan sumber belajar pada suatu lingkungan belajar. Disebut interaksi karena kedua belah pihak, peserta didik dan pendidik saling berkomunikasi yang intens sehingga terjadi pertukaran informasi mengenai suatu obyek pembelajaran.

Dalam hal ini, pendidik menerangkan, menggambarkan, serta mengajak peserta didik terhadap suatu obyek belajar sehingga terjadi suatu peralihan ilmu dan pengetahuan melalui model yang interaktif dan inovatif dengan penekanan pada keaktifan dari kedua belah pihak. Bahwa guru tetap mendominasi suasana, tetapi tetap berupaya mendorong dan memotivasi 
peserta untuk dapat mengeluarkan pertanyaan-pertanyaan yang cerdas dan bernas. Pada tahapan ini, peserta yang berasal dari IGABA sudah memiliki pengetahuan yang cukup. Sedangkan pada tahapan pengetahuan nilai-nilai moral sangat bergantung pada informasi yang diterima peserta karena masing-masing berlatar belakang pendidikan yang berbeda dan variatif.

Nilai moral merupakan dua kata yang disatukan, yaitu nilai dan moral. Nilai menggambarkan pada suatu perbuatan, tingkah, laku, dan ucapan sesorang dalam berinteraksi dengan orang lain. Dalam ini kita mengenal pernyataan etika dan etiket, dimana etika adalah suatu ilmu mengenai tingkah laku manusia untuk mengukur baik dan buruk. Etiket lebih pada ketentuan tidak tertulis yang mengatur gerak dan ucapan manusia.

Moral merupakan pengetahuan yang menyangkut budi pekerti manusia yang beradab moral, yang tercermin pada ajaran yang baik dan buruk perbuatan, serta kelakuan (akhlak). Motivasi, tujuan akhir, dan lingkungan perbuatan. Merupakan faktor-faktor yang menentukan moralitas manusia.Banyak model pendekatan untuk memperkenalkan peserta didik mengenai nilai moral dan pendekatan agama adalah sesuatu yang lazim dipergunakan. Memang pada hakekatnya nilai moral bersinggungan dan pasti bagian dari agama. Namun dalam pelatihan ini memakai pendekatan psikologis dan lebih spesifik lagi bagaimana memperkenalkan nilai moral dengan pendekatan psikologis pada peserta didik yang masih berusia di bawah lima tahun. Ini membutuhkan keterampilan khusus dan disinilah peserta akan memperoleh bimbingan.

Pendekatan psikologis merupakan suatu pendekatan yang digunakan untuk mengetahui kedalalam jiwa seseorang terhadap orang lain dan lingkungan. Pada tahapan ini adalah menggali pengetahuan peserta mengenai tujuan dari pelatihan ini dan sebagian menyatakan belum memahami mengenai pendekatan psikologis dalam menanamkan nilai-nilai moral pada siswa tingkat usia dini. Dibutuhkan keterampilan, ketelatenan, dan kesabaran dalam membimbing siswa yang masih anak-anak belia.

2. Pemahaman dan Pengetahuan Peserta Sesudah Pelatihan

Pemahaman dan pengetahuan peserta terhadap pembelajaran nilai-nilai moral anak usia dini dengan pendekatan psikologis dapat dikatakan meningkat dalam pengertian pengetahuan peserta pelatihan bertambah, hal tersebut dibuktikan dari hasil wawancara dengan peserta, dimana sebanyak 95\% peserta mengatakan bertambah pengetahuan dan wawasannya setelah mengikuti pelatihan. 
Peserta mengatakan akan mempraktekan pembelajaran nilai-nilai moral anak usia dini dengan pendekatan psikologis ini di sekolah masing-masing, sehingga pembelajaran nilai-nilai moral akan semakin berhasil secara efektif dan efesien. Dengan demikian pelatihan ini dikatakan berhasil karena memberikan peningkatan pengetahuan dan wawasan kepada peserta akan sesuatu yang dibutuhkan peserta dalam menjalankan tugasnya sebagai pendidik di tingkat pendidikan Taman Kanak-kanak.

Para peserta menginginkan pelatihan seperti ini dan sejenisnya yang menunjang tugas seorang guru TK secara berkesinambungan, baik diselenggarakan dinas pendidikan maupun swasta yang peduli akan peningkatan kualitas pembelajaran nilai-nilai moral anak usia dini. Pelatihan seperti ini sangat bermanfaat bagi para guru TK untuk menambah ilmu dan wawasan para guru di lingkungan Taman Kanak-Kanak, karena keterbatasaan kemampuan dan wawasaan para guru ini untuk memutakhirkan pengetahuan para guru dalam proses pembelajaran.

3. Kemampuan dan Ketrampilan Peserta akan Pembelajaran Nilai-Nilai Moral dengan Pendekatan Psikologis

Kemampuan dan keterampilan peserta dalam pembelajaran nilai-nilai moral anak usia dini dengan pendekatan psikologis juga meningkat terbukti sebanyak $85 \%$ peserta mengatakan meningkat kemampuan dan keterampilannya dalam pembelajaran nilai-nilai moral anak usia dini dengan pendekatan psikologis. Hal tersebut menjadi indikasi pelatihan pembelajaran nilai-nilai moral anak usia dini dengan pendekatan psikologis berhasil dan memberikan manfaat yang sgnifikan terhadap peserta

4. Praktek Peserta akan Pembelajaran Nilai-Nilai Moral dengan Pendekatan Psikologis

Praktek pembelajaran nilai-nilai moral dengan pendekatan psikologis peserta dapat dikatakan memadai dibuktikan dari hasil observasi yakni $85 \%$ peserta mampu mempraktekkan pembelajaran nilai-nilai moral anak usia dini dengan pendekatan psikologis, Kondisi ini dibuktikan juga ketika peserta praktek pembelajaran nilai-nilai moral anak usia dini dengan pendekatan psikologis di depan peserta lain peserta sangat antusia dan peserta lain memberikan masukan dan tanggapan yang konstruktif untuk kesempurnaan kemampuan peserta pelatihan.

Dengan demikian pelatihan memberikan kontribusi riil terhadap kemampuan peserta akan pembelajaran nilai-nilai moral anak usia dini dengan pendekatan psikologis yang diharapkan akan dipraktekkan di TK 


\section{Islãmadîna \\ JURNAL PEMIKIRAN ISLAM}

masing-masing sehingga pembelajaran nilai-nilai moral anak usia dini semakin berhasil secara efektif dan efesien.

\section{PEMBAHASAN}

Pelatihan pembelajaran nilai-nilai moral anak usia dini dengan pendekatan psikologis pada guru-guru yang tergabung dalam IGABA (Ikatan Guru Bustanul Athfal) Banyumas dimulai dengan perkenalan pelatih dan peserta pelatihan. Kendati sudah saling mengenal, namun dalam perkenalan ini sebenarnya merupakan praktik dan pemberian pemahaman kepada peserta mengenai psikologi. Saat perkenalan terjadi interaksi antara peserta dengan orang lain dan reaksinya, seperti biasa-biasa saja, tertawa, atau bahkan marah. Dalam perkenalan ini tidak ditemukan peserta yang marah, melainkan saling tertawa.

Kemudian setelah perkenalan peserta dilanjutkan dengan pemaparan mengenai tujuan dan target yang diharapkan dari pelatihan ini, serta kritik dan saran dari peserta sebagai feedback sehingga tercapai tujuannya. Setelah perkenalan masuk pada pemberian materi dengan metode ceramah, studi kasus, dan tanya jawab. Narasumber telah menyiapkan materi sesuai dengan tema yang akan disampaikannya, sebagai berikut :

Sesi I pembelajaran nilai-nilai moral anak usia dini dengan pendekatan spiritual; Sesi II praktek langsung pembelajaran nilai-nilai moral anak usia dini dengan pendekatan psikologis oleh peserta yang dibimbing oleh narasumber dan peserta lain memberikan masukan dan tanggapan untuk kesempurnaan pemahaman peserta. Dalam hal ini pendekatan psikologis adalah pendekatan yang melihat karakteristik anak usia dini dalam mengajarkan nilai-nilai moral yakni anak usia 4-5 tahun yang mempunyai ciri-ciri psikologis sebagai berikut :

1. Rasa ingin tahu dan sikap antusias yang kuat.

Keingintahuan anak-anak pada usia balita (bawah lima tahun) sangat tinggi dan ingin menjajalnya. Misalnya, ia berusaha memegang gelas kaca yang berada di meja. Cara memegangnya apa yang ia pahami tanpa tahu resikonya karena yang terpenting adalah gelas terpegang. Ketika bibir gelas dipegang dan kemudian terjatuh justru ia menangis karena kaget dan bukan karena takut dimarahi orang tuanya. Atau, bisa juga jatuhnya gelas justru membuatnya tertawa senang.

2. Memiliki sikap berpetualang yang kuat.

Sikap petualang itu karena rasa keingintahuan yang tinggi sehingga ia berusaha mengerjakan sesuatu apa yang ada benak pikirannya. Melihat 
kucing di jalan, nalurinya langsung mengejar kucing dengan cara apapun. Ia pun memanggilnya berdasarkan suaranya, misalnya : "meong".

3. Anak banyak memperhatikan, membicarakan, atau bertanya tentang berbagai hal.

Ada yang mengatakan anak-anak sekarang sangat kritis dan selalu bertanya pada gurunya. Kewajiban guru memberikan jawaban sesuai kemampuan serapan mereka.

4. Anak senang dengan nyanyian dan permainan

Apa yang akan disampaikan pada anak-anak sebaiknya saat suasana hati anak-anak sedang riang dan itu terjadi saat mereka bernyanyi dan bermain.

5. Minatnya yang kuat untuk mengobservasi lingkungan

Observasi terhadap sesuatu objek yang berbeda dengan lingkungan rumahnya sangat tinggi seiring dengan pengenalannya terhadap dunia luar.

6. Anak aktif melakukan berbagai aktivitas

Makanan makin bergizi dan lingkungan makin kondusif bagi tempat bermain anak membuatnya makin aktif dalam beraktivitas.

7. Anak tidak dapat berlama-lama untuk duduk dan berdiam diri

Ada istilah jangan terjebak pada aktivitas monoton karena tidak bakal disukai anak-anak karena mereka cepat bosan. Ketika suatu objek sudah digali dan rasa ingin tahunya sudah lenyap, maka ia mencari subjek lain yang memikat hatinya.

Sedangkan ciri-ciri psikologis anak usia $5-7$ tahun adalah :

1. Pada tahap berpikir praoperasional dan belajar melalui pengalaman konkrit.

2. Anak senang menyebut nama-nama benda dan mempelajari benda -benda yang ada di lingkungannya.

3. Anak belajar melalui bahasa lisan dan pada tahap ini bahasa nya telah berkembang dengan pesat.

4. Anak sebagai pembelajar memerlukan struktur kegiatan yang jelas dan intruksi spesifik.

Sementara itu ciri-ciri psikologis anak usia dini secara umum adalah :

1. Anak bersifat unik

2. Anak mengekspresikan prilakunya secara relatif spontan

3. Anak bersifat aktif dan energik

4. Anak egosentris

5. Anak memiliki rasa ingin tahu yg kuat dan antusias terhadap banyak hal 


\section{Islãmadîna \\ JURNAL PEMIKIRAN ISLAM}

6. Anak bersifat eksploratif dan petualang

7. Anak umumnya kaya dengan fantasi.

8. Anak masih mudah frustrasi

9. Anak masih kurang pertimbangan dlm melakukan sesuatu

10. Anak memiliki daya perhatian yang pendek

11. Anak merupakan usia belajar yang paling potensial

12. Anak semakin menunjukkan minat terhadap teman

Dengan memahami ciri-ciri psikologis dalam setiap jenjang usia memudahkan pendidik menyusun model-model pembelajaran psikologis yang tepat, kreatif, dan inovatif dalam menanamkan nilai-nilai moral pada anak usia dini. Kelebihan dan kekurangan penyerapan ilmu akan tereliminasi dengan metode yang diajakan para pendidik.

Pada dasarnya peserta pelatihan sudah memiliki dasar keterampilan mengajar dan pengalaman mengajar yang cukup panjang sehingga pelatihan pembelajarannya untuk mengingatkan kembali ingatan peserta. Yang baru sekali diketahui adalah konten atau isi materi pembelajarannya, yaitu nilai moral karena nilai-nilai moral boleh jadi sedang mengalami pergeseran seiring dengan merebaknya media sosial.

Beberapa pergeseran ditengah anak-anak adalah luapan rasa hormat mereka diantaranya dengan memberikan salam atau hormat dulu pada orang tua atau orang yang dituakan. Tentunya perlu dilakukan penelitian mengenai apa yang sesungguhnya terjadi dan bagaimana solusi mengatasinya. Peserta yang berasal dari guru-guru TK Bustanul Athfal Aisyah di Banyumas sudah memiliki pengetahuan dan keterampilan beragama yang mumpuni sehingga moral yang ditanamkan pada peserta didik disesuaikan dengan agama Islam. Penanaman moral ini merupakan bagian dari indoktrinisasi peserta kepada peserta didiknya, yaitu anak usia dini.

Memberikan materinya disesuaikan dengan contoh yang sederhana, seperti tersenyum. Agama Islam menyatakan senyum adalah ibadah. Senyum mudah diucapkan, tetapi sulit untuk dilaksanakan karena masih banyak yang cemberut. Agar anak-anak usia dini tidak takut dan pusing dalam memahami nilai-nilai moral dapat dilakukan dengan mengajaknya bernyanyi, bermain, bercerita dengan contoh teladan Rasulullah Muhammad SAW beserta sahabat-sahabatmya. Dari cerita-cerita tersebut ditanamkan kebiasan-kebiasan moral sehingga kebiasaan itu terekam pada otak anak-anak dan melekat hingga usia lanjut. 
Bercerita dan pembiasaan adalah teknik mudah menanamkan moral sejak dini, dan apalagi kebiasaan masyarakat adalah bertutur. Sudah banyak penelitian mengenai perlunya bercerita pada anak-anak mengandung nilai positif karena berpengaruh pada perilaku anak, mendekatkan emosi anak dengan orang tua, dan sebagai media pendidikan pada anak-anak. Namun demikian, bercerita dan pembiasaan ini pun dapat bertolak belakang dengan target yang sudah kita tetapkan bila terjadi inkonsistensi pendidik dan orang tua.

Misalkan guru dan orang tua mengajak anak-anaknya tidak merokok, tetapi orang tua justru merokok dihadapan anak-anak. Ini membuat anak-anak bingung dan protes karena pernyataan dengan kenyataan sangat berseberangan sehingga si anak akan lebih merekam dan mencontoh kebiasaan daripada cerita. Dengan demikian, rumus efektif dalam menanamkan nilai-nilai moral berdasarkan pendekatan psikologi adalah memberikan contoh. Dengan contoh akan membuat anak-anak cepat menerapkan apa yang sudah dicontohkan pendidik dan orang tuanya.

Bila lebih menekankan pada media akan mengalami banyak kesulitan karena belum seluruh taman kanak-kanak mampu menyediakan fasilitas yang dibutuhkan, seperti laptop dan LCD karena harganya cukup mahal. Disini pendidik harus pandai memanfaatkan sarana dan prasarana yang berada di lingkungan sekolah untuk dijadikan media pembelajaran.

Namun yang lebih penting adalah ide-ide cerita baru harus selalu tersedia dan siapkan pula jawaban-jawaban cerdas, bernas, dan sederhana karena anak-anak sekarang lebih kritis dibandingkan anak-anak masa lalu. Selain itu, penguasaan anak-anak sekarang pada teknologi lebih baik sehingga ini berdampak pada pengetahuan yang mereka peroleh pun lebih banyak. Namun disisi lain pun teknologi menggiring mereka pada perbuatan-perbuatan yang melanggar moral.

Pelatihan ini bertujuan memberikan kiat pada peserta untuk memperoleh ide-ide kreatif dan hasilnya kemampuan dan keterampilan peserta akan pembelajaran nilai-nilai moral anak usia dini dengan pendekatan psikologis juga meningkat begitu juga praktek pembelajaran nilai-nilai moral anak usia dini dengan pendekatan psikologis juga memadai, dalam pengertian para peserta sudah mampu mempraktekkan pembelajaran nilai-nilai moral anak usia dini dengan pendekatan psikologis ini dengan baik, hal tersebut dapat dimaklumi karena para peserta ini sebenarnya sudah mengajar beberapa tahun di Taman Kanak-kanak meraka masing-masing, hanya karena keterbatasan pengetahuan dan wawasan para peserta akan berbagai pendekatan pembelajaran maka perlu selalu diberi pelatihan-pelatihan yang menunjang tugasnya sehingga tugas yang 


\section{Islãmadîna \\ JURNAL PEMIKIRAN ISLAM}

diembannya lebih berhasil secara maksimal.

Berdasarkan wawancara dan observasi dapat diketahui bahwa pelatihan memberikan dampak positif kepada peserta yakni peserta bertambah pengetahuan dan wawasannya akan pembelajaran nilai-nilai moral anak suai dini dengan pendekatan psikologis, sehingga pembelajaran nilai-nilai moral semakin kreatif dan inovatif, tidak monoton, dan selanjutnya pembelajaran akan berhasil secara efektif dan efesien.

Dalam arti pembelajaran nilai-nilai moral anak usia dini yang dilaksanakan oleh guru tidak hanya menggunakan pendekatan intelektual semata tetapi lebih pada pendekatan psikologis yang berdampak pada keberhasilan pembelajaran yakni anak tidak hanya mempunyai pengetahuan nilai-nilai moral semata tapi anak mampu mempraktekkan nilai-nilai moral tersebut dalam kehidupannya (aspek kognitif, afektif dan psikomotorik).

\section{KESIMPULAN}

1. Pembelajaran nilai-nilai moral anak usia dini merupakan pembelajaran yang urgen karena pembelajaran pada tingkat TK menjadi landasan pada pembentukan kepribadian anak selanjutnya

2. Pembelajaran nilai-nilai moral dengan pendekatan psikologis pada anak usia dini menjadi suatu keniscayaan ketika pembelajaran tersebut diharapkan berhasil secara efektif dan efesien

3. Pendekatan psikologis dalam pembelajaran nilai-nilai moral pada anak usia dini dimaksudkan ketika dalam praktek pembelajaran guru selalu mendasarkan pada karakteristik dan ciri khusus kejiwaan anak usia dini, tidak semata-mata pendekatan intelek sehingga pembelajaran lebih berhasil secara efektif dan efesien

4. Pengetahuan dan pemahaman peserta pelatihan akan pembelajaran nilai-nilai moral anak usia dini dengan pendekatan psikologis bertambah terbukti dari hasil wawancara $95 \%$ peserta mengatakan bertambah pengetahuan dan wawasannya

5. Kemampuan dan ketrampilan peserta akan pembelajaran nilai-nilai moral anak usia dini dengan pendekatan psikologis juga meningkat terbukti dari hasil wawancara $85 \%$ peserta mengatakan meningkat kemampuan dan ketrampilannya 
Pelatihan Pembelajaran Nilai-Nilai Moral.............................................. Zakiyah, Ibnu Hasan

6. Praktek pembelajaran nilai-nilai moral anak usia dini dengan pendekatan psikologis juga memadai terbukti dari hasil observasi $85 \%$ peserta mampu praktek dengan baik dan sangat antusias 


\section{Islãmadîna \\ JURNAL PEMIKIRAN ISLAM}

\section{DAFTAR PUSTAKA}

Aqib , 2011, Pedoman Teknis Penyelenggaraan PAUD (Pendidikan Anak usia Dini ), Bandung; Nuansa Aulia.

Asmani, Jamal Ma'mur. 2009. Manajemen Strategis Pendidikan Anak Usia Dini. Yogyakarta : DIVA Press.

Hidayat, 2007, Pendidikan anak usia Dini, Jakarta, Pustaka Pelajar.

http://supriyadiyadi440.blogspot.co.id/2011/07/pendekatan-psikologis-dalam studi-islam.html.

Keputusan Menteri Agama Republik Indonesia Nomor 211 Tahun 2011 tentang Pedoman Pengembangan Standar Nasional Pendidikan Agama Islam pada Sekolah.

Maria J.Wantah. (2005). Pengembangan Disiplin dan Pembentukan Moral Pada Anak Usia Dini. Jakarta: Depdiknas.

Matt Jarvis, 2000, Teori-Teori Psikologi , tarjamah SPA-Teamwork, Bandung, Nusa Media.

M.Nurhamim, 2004, Metodologi Studi Islam, Malang, UMM Press.

Permendiknas Nomor 58 Tahun 2009, Tentang Tingkat Pencapaian Perkembangan Nilai-Nilai Agama dan Moral pada anak.

Undang-Undang Nomor 20 Tahun 2003 tentang Sistem Pendidikan Nasional.

http://www.kemenag.go.id/file/dokumen/UU2003.pdf.

Zakiyah, dkk, 2013, Model pembinaan nilai-nilai agama dan moral pada anak usia dini, Hasil IBM Dikti, LPPM Universitas Muhammadiyah Purwokerto. 